\title{
Tax evasion detection in Nigeria: Analysis of the specific forensic accounting techniques used
}

\author{
Akinadewo, Israel S. \\ Akinkoye, Ebenezer Y. \\ Department of Management \& Accounting \\ Obafemi Awolowo University, Osun State, Nigeria
}

\begin{abstract}
Keywords
Forensic Accounting, Forensic Accounting Tools, Tax Engagement Services, Tax Evasion, Tax Experts.
\end{abstract}

Abstract

The study investigated the specific forensic accounting techniques used in the detection of tax evasion in Nigeria. The study used a self-administered, semi-structured questionnaire, prompting experts' opinion on the type or the combination of the tools of forensic accounting applied in carrying out tax evasion assignments. Krejcie $\mathcal{E}$ Morgan (1970) formula was adopted to determine the sample size of 301 from the population of 1,387, comprising forensic accounting practitioners and tax officials of Lagos State, Nigeria. Descriptive statistics like mean, standard deviation and percentages were applied for data analysis. The study reveals that all the identified 13 forensic accounting techniques were put into use but with diverse opinion. The study also finds out that Benford's Law, Identifying Anomalies' Document Review, Revenue Approach, Business Intelligence, Revenue Approach, Trend Analysis, Net Worth Comparative Method, Data Mining Tools, and Expenditure Approach, among others, were rated as being frequently used. The findings show that there is no agreement as to the specific tools to be adopted for tax evasion detection and no record of it included in the reports to government. The study however, established the use of different types of techniques among the practitioners. Thus, the study recommends that the practitioners should include in the report of their tax evasion engagement to the government, the forensic accounting techniques, or the combination thereof, used along with the respective results.

\section{Introduction}

In the recent times, forensic accounting techniques have been helpful and served as a handy tool and an instrument adopted to tackle corruption, fraudulent practices, bribery and kickbacks, money laundering, and tax evasion, among others. Consequently, forensic accounting at different fora, has also been a subject for professional discourse and scholarly studies. In the developed countries, there are evidences and records of the use of forensic accounting to uncover hidden assets of corrupt people and to detect and prevent fraud related cases. Though, empirical studies are mixed findings, but the general conclusion suggests there is a nexus between fraud detection and reduction and forensic accounting (Mayungbe, 2012; Muehlmann, Burnaby \& Howe, 2012; Al-Sharairi, 2018; Huber \& DiGabriele, 2014). Likewise, in the emerging economies, there were instances in which forensic accounting was utilised to minimize financial improprieties and the findings were in line with that of developed economies (Akinadewo \& Akinkoye, 2019; Mayungbe, 2012; Eiya \& Otalor, 2013; Ehioghiren \& Atu, 2016). There is no doubt, forensic accounting appears to be a veritable tool in the hand of governments, professional bodies, private sector, academia, and other stakeholders in the fight against financial and economic crimes.

In Nigeria, forensic accounting has been deployed to reduce the incidences of financial and economic crimes including tax evasion (Enofe, Okpako \& Atube, 2013; Oyedokun, Enyi \& Dada, 2018; Bassey, 2018; Akinadewo, Akinkoye, Oyedokun \& Asaolu, 2019). For instance, Lagos State which has been in the lead among the states in Nigeria in the engagement of forensic accountants for tax evasion has recorded appreciable achievements through increased tax revenue and additional eligible taxpayers brought into the tax net. The state government through the forensic accountants' efforts, detected tax evaded as much as N13.36 billion, N11.48 billion, N11.13 billion, N11.10 billion and N15.42 billion in 2014, 
2015, 2016, 2017 and 2018 respectively. The effort also brought 330,000, 86,632, 370, 743,261, and 234,142 eligible taxpayers in 2014, 2015, 2016, 2017 and 2018 respectively into the tax net (LIRS, 2019).

The positive effects of the use of forensic accounting has also spurred other states to imbibe in the use for their tax administration. The use of forensic accounting techniques is not limited to the developing or emerging economy alone as many studies have demonstrated the significant role that can be played by forensic accounting in stemming corruption and enhancing efficiency in government circle. There are so many forensic techniques at the disposal of forensic accountants in the literature, but it has been argued that the application of these techniques can vary across economic environment of nations depending on the specific nature and the economic fundamentals. Forensic engagement has been found positively yielding and helpful in Nigeria. There are documented achievements particularly in addressing the menace of tax evasion and the level of efficiency recorded has brought to the fore the need to investigate the specific techniques adopted by the forensic accountants in Nigeria.

\section{Literature Review}

\section{Overview of Forensic Accounting Techniques}

During forensic accounting engagements, the experts deploy the relevant tools for effective detection, prevention, deterrence, and reporting. The rapid advancement in e-commerce and internet have extended fraud opportunities and challenging the fraud fighters, especially forensic accountants to deplore new ideas and effective techniques to detect and prevent financial and economic crimes (Qureshi \& Tazilah, 2015). Researchers have reported that the tools of forensic accounting include Business Intelligence, Revenue Approach, Trend Analysis, Net Worth Comparative Method, Data Mining Tools, and Expenditure Approach Digital Investigation Manager (DIM), Encase, Computer Aided Audit Tools (CAAT), Forensic Toolkit (FTK), Benford's Law, Data Mining Tools, Ratio Analysis and Data Matching, Computer Assisted Review and Document Review, among others (Qureshi \& Tazilah, 2015; Wells, 2012; Wadhwa \& Pal, 2012; Yadav \& Yadav, 2013; Sharma \& Panigrahi, 2012; Biber, 2010; Nigrini, 2011; ACFE, 2018; Oyedokun, 2016; Stankevicius \& Leonas, 2015; Mwanza, 2017; Okoro, Oshoiribhor \& John-Otumu, 2016; Porter \& Crumbley, 2012; Element \& Gee, 2011).

Enyi (2019) however, posited that there is no major difference between the techniques and the already known manual investigative skills of human fraud investigations. The scholar argued that the modern scientific methods merely enhances sharply and broaden the manual investigative skills of human fraud investigators, divided into Managerial Accounting - Trend Analysis, Variance Analysis; and Statistical Inferences - Bendford's Law application and Regression Analysis. Asaolu (2019) also postulated on Ratio Analysis and Digital Analysis like Bendford's Law, Parallel Simulation among others, for the detection of Financial Statement Fraud. However, Association of Certified Fraud Examiners in their 2018 manual made mention that there is also an Indirect Methods of Tracing Financial Transactions. This it said, could reveal that somebody being investigated is living beyond his observed income. This could be through Net Worth Approach, Asset Method by Comparative Net Worth and Expenditures Method (Sources and Application of Funds). Therefore, these techniques need to be evaluated within the context of Lagos State, Nigeria, in identifying those that are mostly used for tax evasion detection assignments.

While the forensic accounting experts have been trained in the skills and knowledge of detecting fraud, the success will mostly be visible with the use of the appropriate fraud detection tools. Thus, the importance of the forensic accounting techniques in the fight against fraudulent practices cannot be underestimated. The increase in e-transactions and its multifaceted nature in relation to the contemporary cloud computing and artificial intelligence have also increased the need for the use of appropriate tools to unearth fraud related activities including tax evasion. In Nigeria, professional bodies like the Institute of Chartered Accountants of Nigeria (ICAN) and the Association of National Accountants of Nigeria (ANAN) have created faculties for the certification of auditors in the knowledge of forensic accounting. Professionals and academics in accounting, law and the related have also come together in forming the Association of Forensic Accounting Researchers (AFAR). Thus, steps have been taken in the creation of awareness of forensic accounting and its efficacy in financial and economic crimes, but the relevant governments have not institutionalized this. In addition, there is no uniformity as to the specific forensic accounting tools applied by the experts in the discharge of their engagement services. 
The need for the engagement of forensic accounting experts become highly necessary both in the private and the public sectors. In the recent past, the management of quoted companies in Nigeria, like the Cadbury Nig Plc., Oceanic Bank Plc (now defunct), Afribank Nig. Plc (now defunct), have involved in fraud against their organizations, which was made possible due to the access to their institutions' data (Enofe, Okpako \& Atube, 2013).

\section{Benford's Law Technique}

Wells (2012) argued that Benford's Law is one of the techniques available for fraud investigators and it assist greatly to achieve success in the field of forensic accounting. Benford's Law describes the sequence in which multiple numbers from real-life sources can be distributed in a specific, non-uniform way (Wells, 2012). It has been established that this technique is applied in the summarization after the classification of the first digit field and the calculation of the observed count percentage (Wadhwa \& Pal, 2012; Wells, 2012). This technique, which was named after Frank Benford (1883-1948) is useful to determine if the variables under study was a result of fraud or unintentional error (Yadav \& Yadav, 2013). Consequently, the concept of Benford's Law, also known as first-digit phenomenon, has been known to mathematicians since 1881 and it is counter-intuitive, difficult to explain in simple terms and has suffered from being described variously as a numerical aberration, an oddity, a mystery, but also as a mathematical gem (Kruger \& Yadavailli, 2017). Despite that, Brenford's Law is germane as a statistical tool that can be applied practically on figures, most especially on fraud detection under forensic audit (Kruger \& Yadavailli, 2017).

\section{Data Mining Tools}

Data mining is about gaining insights and identification of interesting patterns from the data stored in big databases in such a way that these patterns and insights despite of the fact that they are previously unknown, are statistically reliable and actionable (Sharma \& Panigrahi, 2012). The scholars further asserted that it is a mechanism that applies statistical, mathematical, artificial intelligence and machine learning techniques for the extraction and identification of useful information and subsequent gaining of knowledge from a large database.

\section{Ratio Analysis and Data Matching}

Scholars posited that this technique calculates data analysis ratios for key numeric fields (Wadhwa \& Pal, 2012; Yadav \& Yadav, 2013). Ratio analysis gives indications of the financial soundness of corporate organizations and these ratios provide the information on the level of the fraud through the identification of the possibility of its symptoms (Wadhwa \& Pal, 2012; Yadav \& Yadav, 2013).

\section{Relative Size Factor (RSF)}

This technique is the ratio of the largest numbers to the second largest number of a given set and when applied to figures, the unusual variations may be routed from fraud or genuine errors (Wadhwa \& Pal, 2012; Yadav \& Yadav, 2013). The scholars further asserted that if any stray instance is observed beyond the normal range, further investigation may be required which will assist the detection of anomalies or routines.

\section{Computer Assisted Auditing Tools (CAATs)}

These are computer programs that forensic accountants could make use of, in the audit procedure to process data of audit significance in client's information system and at the same time not depending on that client (Wadhwa \& Pal, 2012; Yadav \& Yadav, 2013). This technique assists experts in investigative and forensic accounting assignments to perform auditing procedures such as (a) Testing of transactions and balances in details, (b) the identification of any inconsistencies or significant fluctuations, (c) general testing in addition to computer systems application, (d) sampling program in extracting data for audit testing, and (e) the recording of the calculations performed by accounting systems (Wadhwa \& Pal, 2012; Yadav \& Yadav, 2013).

\section{Net Worth Approach (NWA)}

Biber (2010) argued that there are two methods of determining and verifying taxpayers' income which are the Direct Method and the Indirect Method. The direct method is the specific item relied upon 
in verifying income and expenses by referring to the books and records used in the preparation of the relevant tax computations while the indirect method involves the determination of tax liabilities through an analysis of a taxpayer's financial affairs accumulating information beyond the taxpayer's declaration and formal books and records (Biber, 2010). This indirect method is inclusive of Bank Deposits into the taxpayer's accounts, Cash Expenditure and Net Worth Approach (NWA), among others. Thus, forensic accountants will compare the total assets of the taxpayer or that of tax evader, after deducting the liabilities and used as the criteria for identifying undisclosed income. This approach when used will afford the tax authorities to reduce the incidences of tax evasion.

\section{Net Worth Comparative Method}

This approach is like NWA, but in its own application, the current net worth of the taxpayer will be compared with the value of the cumulative years in identifying the difference and treat as income not disclosed for the current year.

\section{Expenditure Approach}

This involves the use of the expenditure of the taxpayer to determine the undisclosed income. This approach assumes that every expenditure must have its respective source and if this has not been included in the income disclosed by the taxpayer, then the forensic accountants and the tax authorities will treat as undisclosed income and will be adequately taxed. Biber (2010) asserted that the purchasing of capital items by cash, personal and business loan repayments through cash, personal expenses paid with cash, in addition to increases in cash on hand should be determined through an in-depth examination of taxpayer's financial affairs.

\section{Tax Evasion and the Engagement of Tax Experts}

Tax evasion is the non-compliance fully by taxpayers, on the appropriate tax laws as to the performance of the civic responsibilities on tax payments. This could be in non-rendition of the full tax; under reportage of the tax liabilities; manipulation of financial statements which include overstatement and understatement of expenses and income respectively; and falsification of records to gain undue tax benefits. Tax evasion varies across countries and that it follows a geographical pattern: Southern European nations like Italy, Spain and Greece have higher rates of it than Northern European nations (Guerra \& Harrington, 2017). It has been established that with the mind of taxpayers to undercut the tax system, governments will not rely on the judgement of taxpayers in the remittances of tax owed (Slemrod, 2007). In Nigeria, fraudulent practices among Nigerians are some of the hindrances facing the development of the country, which has necessitated the government to set up many anti-corruption agencies in the reduction of cases of fraud and other financial and economic crimes (Ehioghiren \& Atu, 2016). Consequently, and irrespective of its value, tax evasion drastically reduces the number of annual budgets globally, and it is a universal phenomenon that has been in practice, both in the developed and developing nations (McGee \& Gelman, 2009).

Tax evasion is detrimental to economic growth, affecting the developed and the developing economies. For instance, the UK lost about 82.1billion pounds in 2013/2014 to tax evaders, with efforts made to investigate and tackle tax cheats, resulting to about 3.3 billion pounds protected from the hands of tax evaders (Murphy, Tax Research U.K, 2014; HM Revenue \& Customs, Annual Reports, 2017/2018). The alarming rate of tax evasion was noted by the Organisation for Economic Co-operation and Development. OECD (2017), posited that in as much as many taxpayers comply with their tax obligations, there are several non-compliant ones, which has made tax evasion to substantially be occurring, costing billions annually.

In other African countries, tax evasion has been reported in Tanzania, Ghana, South Africa, and Egypt, among others. In Tanzania, tax evasion has been a major issue prior to the establishment of revenue board (Nyang'au, 2016). Egypt, however, lost $\$ 22.3$ billion to tax evaders inn year 2016/2017 (Zaher, 2018). In South Africa, 411 people were investigated on tax evasion with 88 evaders prosecuted (SARS, 2018).

The dwindling revenue in Internally Generated Revenue (IGR) in Lagos State, Nigeria, was the reason behind the engagement of tax consultants, and this brought additional revenue to the government in addition to more eligible taxpayers into the tax net. The efforts of the forensic accountants in tax 
consultancy, positively influenced the IGR of the state with the record of additional revenue but with upward/downward movement of N20.3bn in 2009 to N15.4b in 2018. The number of identified taxpayers also increased from 4,174,927 in 2013 to 5,659,332 in 2018, showing an addition of 1,484,405. It has also been argued that it is technically difficult to study tax evasion due to the non-availability of a single source of information capturing all of it (Alstadsaeter, Johannesen \& Zucman, 2018). Thus, this has called for the governments to seek more of the services of the forensic accountants in tax consultancy.

\section{Methodology}

The study adopted survey method through the administration of structured questionnaire on respondents. The sample size was 301, determined through the application of Krejcie \& Morgan (1970) formula from 1,387 population comprising forensic accountants and tax officials of Lagos State Internal Revenue Service (LIRS).

\section{Data Presentation, Analysis and Discussion of Findings}

Descriptive Statistics on Specific Forensic Accounting Techniques Used in Detecting Tax Evasion in Lagos State

Table 1 shows the responses of the experts on the specific forensic accounting techniques used for the detection of tax evasion in Lagos State. The question was asked on 5-Likert scale showing Strongly Agreed (SA), Agreed (A), Undecided (U), Disagreed (D), and Strongly Disagreed (SD). Among the 301 respondents, none disagreed strongly; 5 respondents $(1.7 \%)$ believed that there were no forensic accounting techniques; 49 respondents $(16.3 \%)$ were undecided; 113 respondents $(37.5 \%)$ agreed that there were forensic accounting techniques for the detection of tax evasion; and 134 respondents (44.5\%) strongly agreed with the question. Thus, 247 respondents $(82 \%)$ of the total respondents of 301, agreed to the fact that there are forensic accounting techniques for tax evasion detection.

Table 1: There are specific Forensic Accounting Techniques used for Tax Evasion Detection in Lagos State

\begin{tabular}{|ll|l|l|l|l|}
\hline & & & & Cumulative \\
\hline Valid & D & 5 & Percent & Valid Percent & $\begin{array}{l}\text { Percent } \\
\text { U }\end{array}$ \\
& 49 & 1.7 & 1.7 & 1.7 \\
& A & 113 & 16.3 & 16.3 & 17.9 \\
SA & 134 & 37.5 & 37.5 & 55.5 \\
Total & 301 & 44.5 & 44.5 & 100.0 \\
\hline
\end{tabular}

Source: Authors' Field Work (2020)

Table 2 shows that the mean on the specific forensic accounting techniques used in the detection of tax evasion in Lagos State, Nigeria was 4.2492 from the minimum mark of 2.00 and maximum mark of 5.00. Thus, this explains the average of the data and with a standard deviation of 0.78382 showing the deviation from the mean.

Table 2: Descriptive Statistics on the Specific Forensic Accounting Techniques used for Tax Evasion Detection in Lagos State

\begin{tabular}{|c|c|c|c|c|c|}
\hline & $\mathbb{N}$ & Minimum & Maximum & Mean & Std. Deviation \\
\hline $\begin{array}{l}\text { Specific } \\
\text { Accounting } \\
\text { Techniques used for } \\
\text { Tax Evasion Detection } \\
\text { in Lagos State } \\
\text { Valid N (listwise) }\end{array}$ & 301 & 2.00 & 5.00 & 4.2492 & .78382 \\
\hline
\end{tabular}

Source: Authors' Field Work (2020)

This study identified from the literature, thirteen techniques that forensic accountants and many investigative auditors use for the effective performance of their engagement services. These are Benford's Law; Data Mining Tools, Ratio Analysis and Data Matching, Identifying Anomalies' Techniques, Computer Assisted Review and document Review, Revenue Approaches, Business Intelligence, Relative 
Size Factors, Trend Analysis, Variance Analysis, Net Worth Method, Net Worth Comparative Method, and Expenditure Approach. The experts' responded as to the techniques that they have made use of, in the detection of tax evasion in Lagos State, Nigeria.

In table 3, 166 respondents (55.1\%) recorded that they have applied Benford's Law technique in tax evasion detection, and 135 respondents (44.9\%) said that they have never used the technique. The table 3 also shows that 117 respondents (38.9\%) recorded that they have used Data Mining Tools in the detection of tax evasion and 184 respondents $(61.1 \%)$ opinionated that they have never used it. The results also showed that 121 respondents $(40.2 \%)$ were of the opinion that they have used Ratio Analysis and Data Matching in the detection of tax evasion and 180 respondents $(59.8 \%)$ opinionated that they have never used it. The table also shows that 148 respondents (49.2\%) recorded that they have used Identifying Anomalies' Techniques in the detection of tax evasion and 153 respondents (50.8\%) opinionated that they have never used it. The results also show that 151 respondents (50.2\%) recorded that they have used Computer Assisted Review and Document Review in the detection of tax evasion and 150 respondents $(49.8 \%)$ reported that they have never used it. The results revealed also that 117 respondents $(38.9 \%)$ opinionated that they have used Revenue Approaches in the detection of tax evasion and 184 respondents $(61.1 \%)$ reported that they have never used it. The result also shows that 132 respondents (43.9\%) opinionated that they have used Business Intelligence in the detection of tax evasion and 169 respondents, representing $56.1 \%$ reported that they have never used it.

The results further show that 132 respondents (43.9\%) recorded that they have used Relative Size Factors in the detection of tax evasion and 169 respondents (56.1\%) opinionated that they have never used it. Table 3 also shows that 138 respondents (45.8\%) recorded that they have used Trend Analysis in the detection of tax evasion and 163 respondents (54.2\%) reported that they have never used it. The table also shows that 112 respondents (37.2\%) recorded that they have used Variance Analysis in the detection of tax evasion and 189 respondents $(62.8 \%)$ reported that they have never used it. The results further show that 80 respondents $(26.6 \%)$ recorded that they have used Net Worth Method in the detection of tax evasion and 221 respondents $(73.4 \%)$ reported that they have never used it. The results also show that 95 respondents (31.6\%) opinionated that they have used Net Worth Comparative Method in the detection of tax evasion and 206 respondents $(68.4 \%)$ reported that they have never used it. The table further shows that 107 respondents $(35.5 \%)$ recorded that they have used Expenditure Approach in the detection of tax evasion and 194 respondents $(64.5 \%)$ reported that they have never used it.

Table 3 also show the descriptive statistics' results of the mean and the standard deviation of the respondents' view on the various forensic accounting techniques used in the detection of tax evasion. The mean score on the use of Benford's Law was 0.4485 on a minimum mark of 0.00 and maximum mark of 1.00 , and the mean scores for the other tools. The various results show that no specific technique was common among the experts but all of them were put into various use for tax evasion detection at different level of usage.

Table 3: Frequency Table and Descriptive Statistics on the use of Forensic Accounting Techniques in Tax Evasion Detection

\begin{tabular}{|c|c|c|c|c|c|c|c|c|c|c|c|}
\hline & \multirow[t]{2}{*}{$\mathrm{N}$} & \multicolumn{2}{|l|}{ Used } & \multicolumn{2}{|c|}{ Never Used } & \multicolumn{2}{|c|}{ Cumm. } & \multirow[t]{2}{*}{ Min } & \multirow[t]{2}{*}{ Max. } & \multirow[t]{2}{*}{ Mean } & \multirow[t]{2}{*}{ Std. Dev. } \\
\hline & & Freq. & $\%$ & Freq. & $\%$ & Freq. & $\%$ & & & & \\
\hline Benford's Law & 301 & 166 & 55.1 & 135 & 44.9 & 301 & 100.0 & .00 & 1.00 & .4485 & .49817 \\
\hline Data Mining Tools & 301 & 117 & 38.9 & 184 & 61.1 & 301 & 100.0 & .00 & 1.00 & .6113 & .48827 \\
\hline $\begin{array}{l}\text { Ratio Analysis and Data } \\
\text { Matching }\end{array}$ & 301 & 121 & 40.2 & 180 & 59.8 & 301 & 100.0 & .00 & 1.00 & .5980 & .49112 \\
\hline $\begin{array}{l}\text { Identifying Anomalies' } \\
\text { Document Review }\end{array}$ & 301 & 148 & 49.2 & 153 & 50.8 & 301 & 100.0 & .00 & 1.00 & .5083 & .50076 \\
\hline
\end{tabular}




\begin{tabular}{|c|c|c|c|c|c|c|c|c|c|c|c|}
\hline $\begin{array}{l}\text { Computer Assisted Review } \\
\text { and Document Review }\end{array}$ & 301 & 151 & 50.2 & 150 & 49.8 & 301 & 100.0 & .00 & 1.00 & .4983 & .50083 \\
\hline Revenue Approach & 301 & 117 & 38.9 & 184 & 61.1 & 301 & 100.0 & .00 & 1.00 & .6113 & .48827 \\
\hline Business Intelligence & 301 & 132 & 43.9 & 169 & 56.1 & 301 & 100.0 & .00 & 1.00 & .5615 & .49703 \\
\hline Relative Size Factor & 301 & 132 & 43.9 & 169 & 56.1 & 301 & 100.0 & .00 & 1.00 & .5615 & .49703 \\
\hline Trend Analysis & 301 & 138 & 45.8 & 163 & 54.2 & 301 & 100.0 & .00 & 1.00 & .5415 & .49910 \\
\hline Variance Analysis & 301 & 112 & 37.2 & 189 & 62.8 & 301 & 100.0 & .00 & 1.00 & .6279 & .48417 \\
\hline Net Worth Method & 301 & 80 & 26.6 & 221 & 73.4 & 301 & 100.0 & .00 & 1.00 & .7342 & .44248 \\
\hline $\begin{array}{l}\text { New Worth } \\
\text { Comparative Method }\end{array}$ & 301 & 95 & 31.6 & 206 & 68.4 & 301 & 100.0 & .00 & 1.00 & .6844 & .46553 \\
\hline $\begin{array}{l}\text { Expenditure Approach } \\
\text { Valid N (listwise) }\end{array}$ & 301 & 107 & 35.5 & 194 & 64.5 & 301 & 100.0 & .00 & 1.00 & 6445 & .47946 \\
\hline
\end{tabular}

Source: Authors' Field Work (2020)

\section{Policy Implications and Recommendations}

Tax evasion has been established as a way of cheating on tax returns and having an economic, psychological, and social effects on the society (Folayan \& Adeniyi, 2018). Thus, tax audit is imperative in assisting the government to collect the appropriate tax revenue necessary for budget implementation (Harelimana, 2018). This exercise and the engagement of forensic accountants in Lagos State, Nigeria has not only reduced the rate of tax evasion but brought additional taxpayers into the tax net. However, the specific techniques used by these experts have not been well documented, hence, the need for the empirical investigation. Consequently, this study examined the identified forensic accounting tools used for the detection of tax evasion. The study finds out that there are techniques in use in tax evasion detection. The study also established that all the techniques were applied for tax evasion detection but at mixed and different levels. The study also reveals that the forensic accounting techniques were utilized in tax evasion detection and reduction. Consequently, the study shows that the techniques of forensic accounting, when applied, will reduce the rate of tax evasion, and improve the tax revenue of governments for economic development and growth.

Based on these findings, it is recommended that government should continue with the use of forensic accountants for tax evasion matters. The study also suggests that the engagement letter should 
indicate the need for the experts to disclose the respective tools used for the assignments. The study further recommends that government should develop a tax evasion discovery technique and make it a national policy.

\section{References}

Association of Certified Fraud Examiners (2018). Fraud Examiners Manual, International Edition, 1990-2018, ISBN 978-1-889277.

Akinadewo, I. S. \& Akinkoye, E. Y. (2019). Application of Forensic Accounting on Fraud Detection in Nigerian Deposit Money Banks (DMBs). Proceedings of the $15^{\text {th }}$ RSEP International Conference on Economics, Finance \& Social Sciences, 26-28 November 2019, University of Washington Rome Center, Rome, Italy, ISBN: 978-605-80676-84/December 2019.

Akinadewo, I. S., Akinkoye, E. Y., Oyedokun, G. E. \& Asaolu T. O. (2019). Tax Audit and Direct Tax Revenue in Lottery Industry in Nigeria: Can Forensic Accounting Bridge the Gap? Fountain University Osogbo Journal of Management (FUOJM), 4(2), 73-92.

Al-Sharairi, M. E. (2018). The Role of Forensic Accounting in Limiting Tax Evasion in the Jordanian Public Industrial shareholding companies through the Perspective of Jordanian Auditors. International Journal of Economics and Finance, 10(1), 233-243.

Alstadsaeter, A., Johannesen, N., Zucman, G. (2018). Tax Evasion and Inequality.Norwegian University of Life Sciences, 1-58. www.gabriel-zucman.eu/leaks.

Asaolu, T. O. (2019). Forensic Accounting Techniques for the Detection of Financial Statement Fraud. Forensic Accounting Research Developments, ISBN: 978-978-56669-9-1, 58-91.

Bassey, E. B. (2018). Effect of Forensic Accounting on the Management of Fraud in Microfinance Institutions in Cross River State. IOSR Journal of Economics and Finance, 9(1), 79-89.

Biber, E. (2010). Revenue Administration: Taxpayer Audit - Use of Indirect Methods. International Monetary Fund, Technical Notes and Manuals, 10/05.

https://www.imf.org/external/pubs/ft/tnm/2010/tnm1005.pdf

Ehioghiren E. E. \& Atu, O. O. K. (2016). Forensic Accounting and Fraud Management: Evidence from Nigeria. Igbinedion University Journal of Accounting, 2, 245-283.

Eiya O. \& Otalor, J. (2013). Forensic Accounting as a Tool for Fighting Financial Crime in Nigeria. Research Journal of Finance and Accounting, 4(6), 18-25.

Element, B. \& Gee, S. (2011). IDEAScript - Relative Size Factor Test (RSF).

Enofe, A. O., Okpako, P. O. \& Atube E. N. (2013). The Impact of Forensic Accounting on Fraud Detection. European Journal of Business and Management, 5(26), 61-72.

Enyi, E. P. (2019). Forensic Accounting Investigations: A Scientific Deductive Approach. Forensic Accounting Research Developments, ISBN:978-978-56669-9-1, 92-118.

Guerra, A. \& Harrington, B. (2017). Culture, Tax Evasion and Tax Morale: An Experimental Study of Italy and Denmark. Copenhagen Business School, Department of Business and Politics, 1-52.

Harelimana, J. B. (2018). Effects of Tax Audit on Revenue Collection in Rwanda. Global Journal of Management and Business Research: Accounting and Auditing, 18(2,1), 1-11.

Huber, W.D. \& DiGabriele, J. A. (2014). Research in Forensic Accounting - What Matters? Journal of Theoretical Accounting Research, 10(1), 40-70.

https://www.researchgate.net/publication/273142341_Research_in_forensic_accounting__what_ma tters.

Kruger, P. S. \& Yadavalli, V. S. S. (2017). The Power of One: Benford's Law. South African Journal of Industrial Engineering, 28 (2), 1-13.

Lagos State Internal Revenue Service (2019). Official communication dated 7th June 2019.

Oyedokun, G. E. (2016). Forensic Accounting Investigation Techniques: Any Rationalization? SSRN. www.papers.ssrn.com.

Oyedokun, G. E., Enyi, P. E. \& Dada, S. O. (2018). Forensic Accounting Techniques and Integrity of Financial Statements: An Investigative Approach. Journal of African Interdisciplinary Studies (JAIS), 2(3).

Qureshi, S. \& Tazilah, M. D. A. B. K. (2015). Forensic Accounting Tools in Detecting \&

Investigating Fraud in Malaysia. International Conference on Business, Accounting, Finance, and Economics

(BAFE 2015), Universiti Tunku Abdul Rahman, Kampar, Perak, Malaysia.

www.researchgate.net/publication/313160670.

Mayungbe, R. (2012). Forensic Accounting in Nigeria. www.nafanet.com

McGee, R. W., Gelman, W. (2009). Opinions on the Ethics of Tax Evasion: A Comparative Study of the USA and Six Latin American Countries. Akron Tax Journal, 24(69), 69-91. 
Muehlmann, B. W., Burnaby, P. \& Howe, M. (2012). The Use of Forensic Accounting Experts in Tax Cases as Identified in Court Opinions. Journal of Forensic \& Investigative Accounting, 4(2), 1-34.

Murphy, R. (2014). Tax Evasion in 2014- and what can be done about it. Public and Commercial Services Union, 1-83. www.pcs.org.uk

Mwanza, M. (2017). Fraud Detection on Big Tax Data Using Business Intelligence, Data Mining Tool. A Case of Zambia Revenue Authority. The University of Zambia, School of Engineering, Master of Engineering in Information Communication Technology, Security, Dissertation, 1-97.

Nigrini, M. J. (2012). Benford's Law: Application for Forensic Accounting, Auditing, and Fraud Detection. John Wiley \& Sons, Inc., New Jersey, 1-330.

Nyang'au, S. M. (2016). An Investigation of the causes of tax evasion and tax Avoidance in Tanzania: A case study of Magu District. International Journal of Humanities and Social Science Research, 2(6), 17-20.

Organisation for Economic Co-operation and Development - OECD (2017). Technology Tools to Tackle Tax Evasion and Tax Fraud. https://www.oecd.org/tax/crime/technology-tools-to-tackle-tax-evasion-and-tax-fraud.pdf

Okoro, F. M., Oshoiribhor, E. O. \& John-Otumu, M. A. (2016). A Framework for Detecting Fraudulent Activities in Edo State Tax Collection System Using Investigative Data Mining. International Journal of Artificial Intelligence and Applications, 7(3), 11-21.

Porter, S. F. \& Crowmbley, D. L. (2012). Teaching Interview Techniques to Forensic Accountants Is Critical. Journal of Forensic \& Investigative Accounting, 4(1), 122-146.

Sharma, A. \& Panigrahi, P. K. (2012). A Review of Financial Accounting Fraud Detection based on Data Mining Techniques. International Journal of Computer Applications, 39(1), 37-47.

Slemrod, J. (2007). Cheating Ourselves: The Economics of Tax Evasion. Journal of Economic Perspectives, 21(1), 2548.

Stankevicius, E. \& Leonas, L. (2015). Hybrid Approach Model for Prevention of Tax Evasion and Fraud. Procedia Social and Behavioral Sciences, 213, 383-389.

South African Revenue Service - SARS (2018). Annual Report 2017/18. ISBN: 978-0-621-46404-7. www.sars.gov.za

Wadhwa, L. \& Pal, V. (2012). Forensic Accounting and Fraud Examination in India. International Journal of Applied Engineering Research, 7(11).

Wells, J. T. (2012). Foreword on Benford's Law: Application for Forensic Accounting, Auditing, and Fraud Detection. John Wiley \& Sons, Inc., New Jersey, xi-xii.

Yadav, S. \& Yadav, S. (2013). Forensic Accounting: A New Dynamic Approach to Investigative Fraud Cases. International Journal of Multidisciplinary Management Studies, 3(7), 1-9.

Zaher, H.A. (2018). Bitter options for Egypt as tax evasion persist.

The Arab Weekly. www.thearabweekly.com/bitter-options-egypt-tax-evasion-persists. 